\title{
Distribution patterns, abundance and population dynamics of the euphausiids Nyctiphanes simplex and Euphausia eximia off the west coast of Baja California, Mexico
}

\author{
J. G. Gómez \\ Centro Interdisciplinario de Ciencias Marinas, Departamento de Plancton y Ecología Marina, Apartado Postal 592, \\ C.P. 23000 La Paz, Baja California Sur, Mexico
}

\begin{abstract}
Distribution patterns and population structure of the euphausiids Nyctiphanes simplex and Euphausia eximia were examined in the California Current off the west coast of Baja California, Mexico, with emphasis on the southern part near Bahia Magdalena, in relation to temperature, zooplankton biomass, distance from the coast as a function of depth, and interannual variability. The data were collected in 6 surveys from May 1986 to October 1987. High densities of $N$. simplex were found in the shallow coastal waters $(<300 \mathrm{~m})$. For $E$. eximia, the maximum abundance occurred offshore at stations with depths of 200 to $3000 \mathrm{~m}$. These distribution patterns (offshore-inshore) remained relatively constant throughout the surveys, but the latitudinal distributions showed important variations in relation to the current patterns of the region and seasonal differences in the upwelling events, particularly near Bahia Magdalena ( 24 to $25^{\circ} \mathrm{N}$ ). Both species displayed continuous breeding, with 25 to $77 \%$ of the adult female $N$. simplex in different fertilized stages. A slightly lower proportion of $E$. eximia females were reproductively active ( 37 to $48 \%$ ). The breeding areas, indicated by early stages (calyptopes) and adults in the reproductive phase, showed that $N$. simplex is dependent on the upwelling system along Baja California. High densities are maintained during spring and summer, then decrease during autumn as the physical environment changes. The population dynamics of $E$. eximia indicated breeding areas offshore with a continuous recruitment. Breeding areas were found in regions of relatively low biological production. Maximum abundance occurred during autumn.
\end{abstract}

KEY WORDS: Nyctiphanes simplex - Euphausia eximia Population dynamics - Baja California

\section{INTRODUCTION}

This paper describes the distribution patterns and population dynamics of Nyctiphanes simplex and Euphausia eximia found along the west coast of Baja California, Mexico. These species, along with Nematoscelis difficilis, dominate the euphausiid fauna off the Pacific coast of Baja California, an area located in the transition zone of the California Current and the Eastern Tropical Pacific (Brinton 1960, 1962, 1979 , Gómez 1992, Lavaniegos 1992, 1993, 1994). N. simplex is the most abundant euphausiid in the nearshore waters of the eastern subtropical Pacific, including the Gulf of California (Brinton \& Townsend 1980), followed by the temperate species $N$. difficilis in the north and
E. eximia inhabiting the marginal productive zone in the eastern tropical Pacific Ocean (Brinton 1979). At times, these species dominate the non-copepod zooplankton in both numbers and biomass.

Several studies have examined the general biology of Nyctiphanes simplex and Euphausia eximia in the California Current System; horizontal and vertical distribution (Brinton 1962, 1967, 1979, 1981, Youngbluth 1975, 1976), larval development (Boden 1951, Knight 1980, Lavaniegos 1992, 1994, Gómez in press), and population dynamics (Gómez 1992, Lavaniegos 1993, 1994). These studies were carried out because of increasing interest in production dynamics in inshore waters with high biological production. Little attention has been paid to the population dynamics of $N$. sim- 
plex and E. eximia, particularly in the southernmost part of the Pacific coast of Baja California where the strongest changes in environmental conditions occur (Gómez \& Hernández in press). Species known to be important constituents of the diet of many fish species off Baja California and in the Gulf of California include Merluccius productus (Bailey et al. 1982), Thunnus maccoyii (Olson 1980), Caulolatilus princeps (Caraveo 1991), and Mobula lucasana (Gendron 1992). Euphausiids are important in the transfer of energy from lower to higher trophic levels, so they have farreaching effects on fish stock dynamics. Sears (1987) and Gendron $(1990,1992)$ detected feeding activity of the blue whale Balaenoptera musculus, fin whale $B$. physalus, and Bryde's whale $B$. edeni associated with daytime surface swarms of $N$. simplex in the Gulf of California. It is possible that these relationships occur along the Pacific coast of Baja California. Recently, studies carried out by Lavaniegos $(1993,1994)$ examined the biology and population dynamics of the euphausiids in the northern part of the west coast of Baja California. The present study was undertaken to examine distribution patterns and population dynamics (maturity size, longevity) of $N$. simplex and $E$. eximia, with particular emphasis on the southern part off the west coast of Baja California, and to obtain a better understanding of the key position of euphausiids in the coastal and offshore food chains of this region.

\section{MATERIALS AND METHODS}

Field sampling. Euphausiids were collected during 6 oceanographic cruises made along the west coast of Baja California during May, June, August, and November 1986, and July and October 1987. The sampling grid extended from 23 to $29^{\circ} \mathrm{N}$ and stations were located up to $160 \mathrm{~km}$ offshore (Fig. 1). Zooplankton samples were collected at each station by means of Bongo nets fitted with a flowmeter (General Oceanics) and with 300 and $500 \mu \mathrm{m}$ mesh nets towed from $210 \mathrm{~m}$ to the surface, following the method of Smith \& Richardson (1977). In the present study, only samples taken by the $500 \mu \mathrm{m}$ mesh net were used. With the exception of the first calyptopis stage, all other stages were represented in the collection of $500 \mu \mathrm{m}$ mesh net. The data for zooplankton biomass were normalized to $\mathrm{ml} 1000 \mathrm{~m}^{-3}$ according to Beers (1976). The mean of the monthly upwelling indices was obtained from Bahia Magdalena $\left(24^{\circ} \mathrm{N}, 113^{\circ} \mathrm{W}\right)$ and Punta Eugenia $\left(27^{\circ} \mathrm{N}, 116^{\circ} \mathrm{W}\right)$ (Anonymous 1990). According to Bakun \& Nelson (1977), these values signify volume transported offshore in the surface Ekman layer.

Euphausiid analysis. Abundant samples were split using a Folsom splitter. Depending on the density of

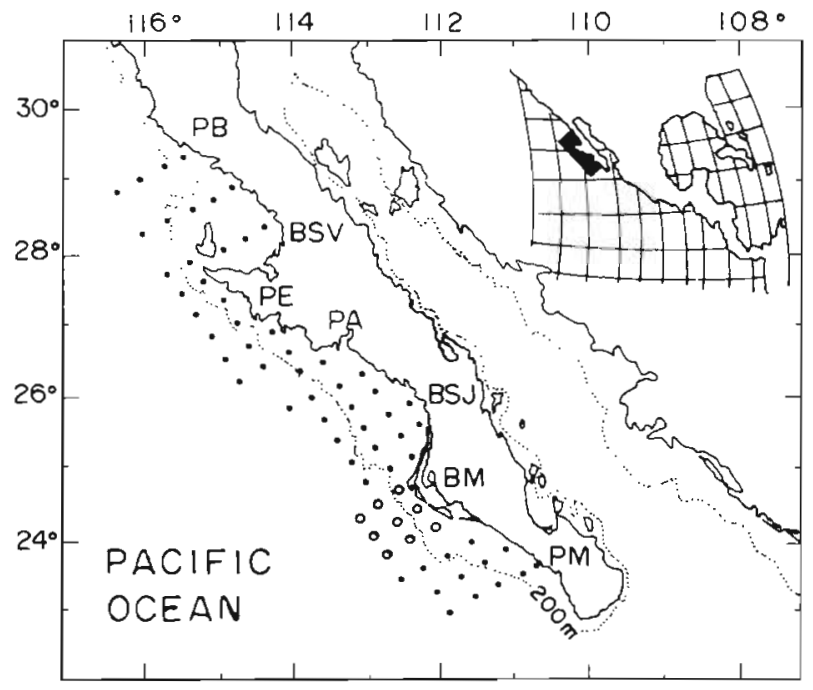

Fig. 1. Study area, off the west coast of Baja California, Mexico. Stations sampled during May 1986, July and October 1987. Open circles denote area (Bahia Magdalena) where population dynamics were studied during May, June, August, November 1986, July and October 1987. PB: Punta Baja; BSV: Bahia Sebastián Vizcaíno; PE: Punta Eugenia; PA: Punta Abreojos; BSJ: Bahia San Juanico; BM: Bahia Magdalena; PM: Punta Marquez. The dotted line denotes $200 \mathrm{~m}$ isobath

euphausiids, 25,50 , or $100 \%$ of the sample was examined. The euphausiids collected were identified as calyptopes, furciliae, juveniles, or adults, then counted. The sexual maturity of the euphausiids was determined by identifying the spermatophore of the males and looking for the internal ripe ovary and ovigerous sacs of the females of Nyctiphanes simplex and for the spermatophore adhering to the thelycum of the females for Euphausia eximia (Mauchline \& Fisher 1969, Brinton 1978). Spermatophores in female N. simplex were not recorded because they were seldom present, probably due to loss during preservation. Four ovarian stages were assigned according to the scheme proposed by Mauchline (1968). In stage I, eggs are small and immature. They grow through stage II when the cytoplasmic space increases in size. Stage III is when yolk globules appear throughout the cytoplasm. The ovaries reach maturity at the end of stage IV when the eggs become large and opaque and are filled with globules of yolk. Ovigerous females were included for $N$. simplex. The numbers of euphausiids were normalized to ind $1000 \mathrm{~m}^{-3}$ of filtered water.

At selected stations in the region, 24 to $25^{\circ} \mathrm{N}$ near Bahia Magdalena (the only area sampled during all surveys), the population dynamics was studied. The total length (from the posterior of the eye to the end of the telson, not including spines) of all stages of both species was measured. Size-frequency distributions of Nyctiphanes simplex and Euphausia eximia were 
obtained for each month. Two-way ANOVA was used to compare the total abundance by stages (calyptopes, furciliae, juveniles, and adults) taken in different cruises and in inshore $(<200 \mathrm{~m})$ and offshore $(>200 \mathrm{~m}$ ) zones. Finally, an analysis of the mean of total body length for adults of both species between surveys and inshore and offshore regions was made.

\section{RESULTS}

\section{Horizontal distribution and spatial variability}

Distribution patterns and abundances of Nyctiphanes simplex and Euphausia eximia in May (spring) and July (summer) 1986, and October (autumn) 1987 are presented in Fig. 2. During May 1986 the low coastal surface temperature $\left(15\right.$ to $\left.18^{\circ} \mathrm{C}\right)$ indicated maximum upwelling of the California Current. The highest zooplanktonic biomass occurred during this month (Fig. 2A). In July 1987, the California Current had an influence only north of Bahia San Juanico with low surface temperatures and high zooplanktonic biomass concentrations. Southward, the surface temperature increased to $27^{\circ} \mathrm{C}$ indicating tropical water advection to the north (Fig. 2B). In October 1987, the surface temperature increased to between 21 and $28^{\circ} \mathrm{C}$. The zooplanktonic biomass decreased abruptly to $<500 \mathrm{ml} 1000 \mathrm{~m}^{-3}$ and the upwelling appeared weaker (Fig. 2C).

Fig. 2 also shows the inconsistent distribution patterns of both species at different upwelling intensities (May 1986, July 1987) and the weak upwelling during October 1987. During these months, high densities of larvae of Nyctiphanes simplex were recorded close to the coast, reaching maximum abundance ( $>10000$ ind. $\left.1000 \mathrm{~m}^{-3}\right)$ at Punta Eugenia $\left(28^{\circ} \mathrm{N}\right)$, Punta Abreojos $\left(26^{\circ} \mathrm{N}\right)$ and in Bahia Magdalena $\left(24^{\circ} \mathrm{N}\right)$. Euphausia eximia larvae and adults were found along the shelf break $>200 \mathrm{~m}$ depth. Larvae were abundant in the southern sampling area.

According to the average monthly upwelling index, the upwelling near Punta Eugenia was more intense than in Bahia Magdalena during spring and early summer (Fig. 3A). The seasonal trend during 1986 and 1987 coincided with the general trend of upwelling intensities reported by Bakun \& Nelson (1977) and Huyer (1983). Offshore transport was found throughout the year. Sea surface temperatures (SST) were higher in Bahia Magdalena than at Punta Eugenia. Lower values were recorded from January to June, increasing abruptly (about $6^{\circ} \mathrm{C}$ in Bahia Magdalena, and about $4^{\circ} \mathrm{C}$ at Punta Eugenia) between July and October in spite of significant offshore Ekman transport. The SST then began to decrease in November and December. This pattern was similar in both years (Fig. 3B).
Average densities of Nyctiphanes simplex, Euphausia eximia, and other species (mainly Nematoscelis difficilis, Nematobrachion flexipes, and Euphausia gibboides) along the entire west coast of Baja California (23 to $29^{\circ} \mathrm{N}$ ), at Punta Eugenia (28 to $29^{\circ} \mathrm{N}$ ) and in Bahia Magdalena (24 to $25^{\circ} \mathrm{N}$ ) are presented in Table 1. Abundance is expressed as a function of station depth and includes data of all surveys made during 1986 and 1987. N. simplex accounted for $100 \%$ of the euphausiids in depths shallower than $50 \mathrm{~m}$. Larvae and adults of this species accounted for more than $90 \%$ of the euphausiids at stations with depths of less than $300 \mathrm{~m}$. Larvae and adults of $E$. eximia accounted for 12 to $31 \%$ of the total abundance at stations $>500 \mathrm{~m}$ depth and located further offshore (Table 1).

The population of Nyctiphanes simplex peaked near the coast at depths $<300 \mathrm{~m}<96 \mathrm{~km}$ from the coast) indicating reproduction areas close to the coast (Fig. 4A). Euphausia eximia showed 2 population peaks, one down to $400 \mathrm{~m}$ and $36 \mathrm{~km}$ off the coast and a second down to $2500 \mathrm{~m}$ and $>160 \mathrm{~km}$ off the coast, particularly of females (non-reproductive) and males in the reproductive phase (Fig. 4B). Except for furciliae and males with spermatophores, a significant difference in abundance offshore-inshore was recorded for all stages of $N$. simplex (Table 2, 2-way ANOVA, $p<0.05)$. These were more abundant inshore over the continental shelf than in oceanic offshore waters. For E. eximia, the differences in abundance were only significant for calyptopes and females (Table 2, 2-way ANOVA, p < 0.05). These were more abundant in the offshore waters.

\section{Temporal variability of euphausiid abundance in Bahia Magdalena}

Average densities (ind. $1000 \mathrm{~m}^{-3}$ ) for Bahia Magdalena from May 1986 to October 1987 are presented in Table 2. For this period, Nyctiphanes simplex calyptopes and furciliae had similar densities during all surveys and showed no significant difference in their abundance (2-way ANOVA, p > 0.5). Adults were most abundant during May and June 1986, decreasing thereafter. The abundance and the relatively high percentage of ripe $N$. simplex females and males with spermatophores from May to August 1986 indicates that this species breeds mainly during spring and summer at these latitudes ( 24 to $25^{\circ} \mathrm{N}$ ) (Table 2). The Euphausia eximia population showed similar densities during all surveys and showed no significant differences in their seasonal abundance. However, larger mean densities were found during August and November 1986, and October 1987, when the average 

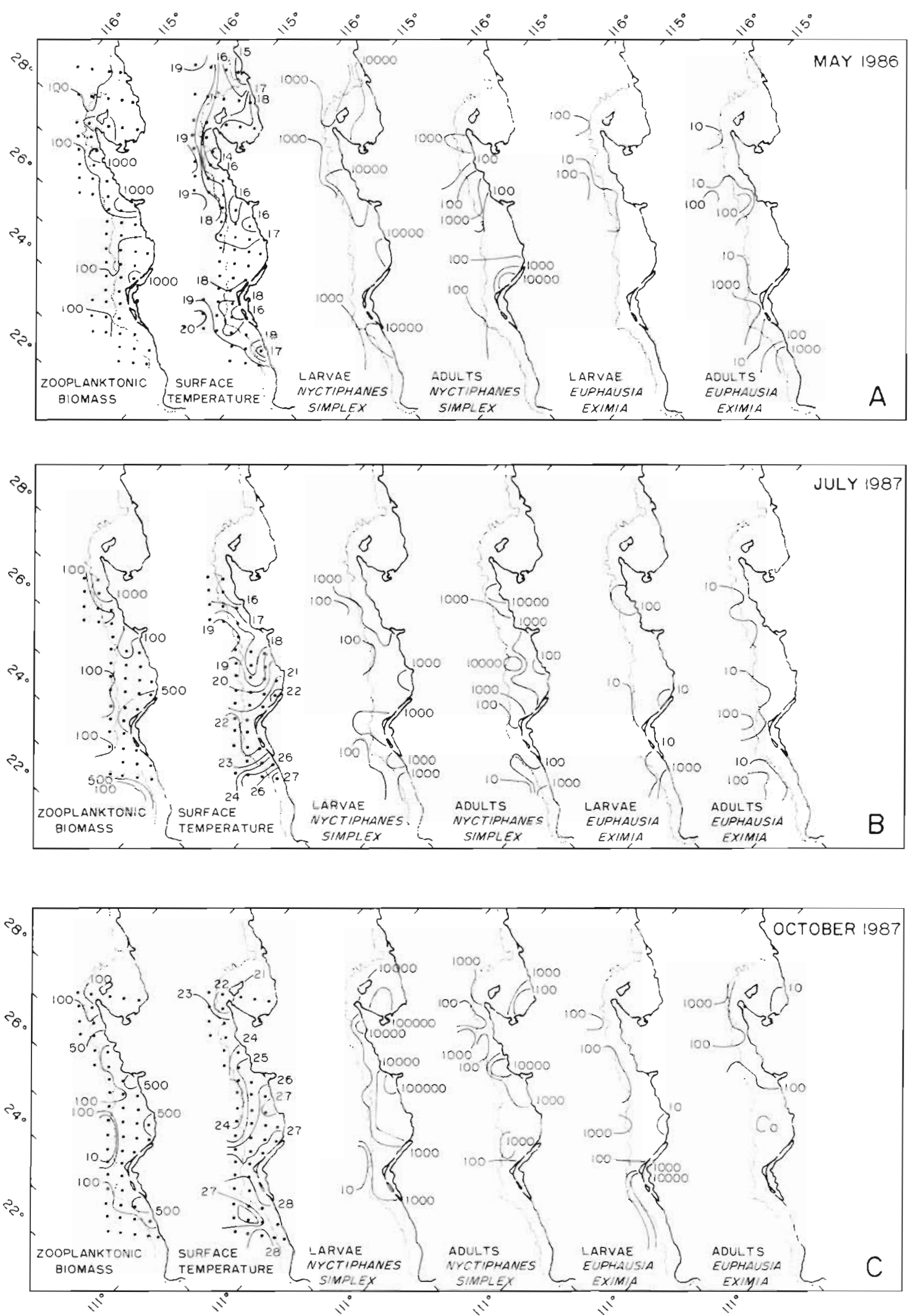

Fig. 2. Nyctiphanes simplex and Euphausia eximia. Density (ind. $1000 \mathrm{~m}^{-3}$ ) and distribution of larvae and adults in (A) May 1986 and (B) July and (C) October 1987 off the west coast of Baja California. Surface temperatures ( ${ }^{\circ} \mathrm{C}$ ) and zooplanktonic biomass $\left(\mathrm{mI} 1000 \mathrm{~m}^{-3}\right)$ are also shown. The dotted line denotes $200 \mathrm{~m}$ isobath 

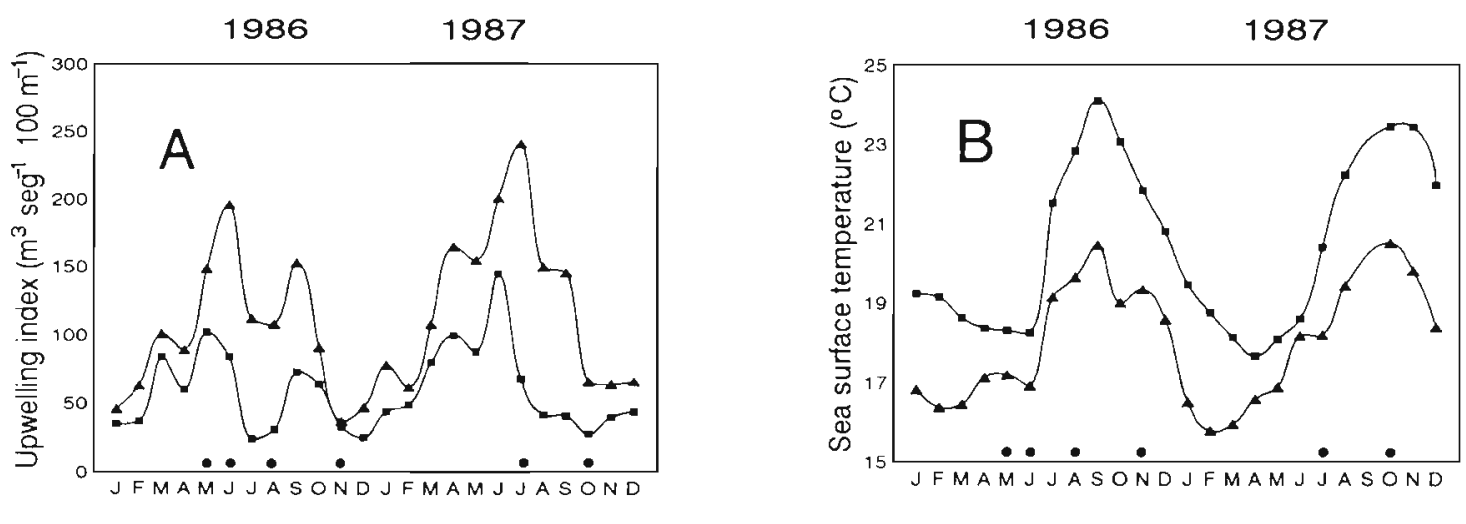

- Bahia Magdalena - Punta Eugenia

Fig. 3. (A) Mean of the monthly upwelling index $\left(\mathrm{m}^{3} \mathrm{seg}^{-1}\right.$ per $100 \mathrm{~m}$ of coastline) and (B) sea surface temperature $\left({ }^{\circ} \mathrm{C}\right) \mathrm{during} 1986$ and 1987. Data from Anonymous (1990). Circles indicate the months samples were taken

SST was greater than $23^{\circ} \mathrm{C}$. The percentage of ripe E. eximia females and males with spermatophores during all months indicates that this species breeds continuously throughout the seasons near Bahia Magdalena.

\section{Population dynamics, life span, and growth rates in Bahia Magdalena}

The size-frequency distribution and population structure of Nyctiphanes simplex showed temporal

Table 1. Nyctiphanes simplex, Euphausia eximia and other euphausiid species. Average density (ind. $1000 \mathrm{~m}^{-3}$ ) as a function of depth along the west coast of Baja California during May, June, August, November 1986, July and October 1987. Percentage that $N$ simplex and $E$. eximia comprised of total euphausiids is shown in parentheses. Densities are given for entire sampling area (including Punta Eugenia and Bahia Magdalena), for Punta Eugenia, and for Bahia Magdalena area alone. No data available for several depths

\begin{tabular}{|c|c|c|c|c|c|c|}
\hline \multirow[t]{2}{*}{ Depth $(m)$} & \multicolumn{2}{|c|}{ N. simplex } & \multicolumn{2}{|c|}{ E. eximia } & \multicolumn{2}{|c|}{ Other euphausiids } \\
\hline & Larvae & $\begin{array}{c}\text { Juveniles } \\
\text { and adults }\end{array}$ & Larvae & $\begin{array}{l}\text { Juveniles } \\
\text { and adults }\end{array}$ & Larvae & $\begin{array}{l}\text { Juveniles } \\
\text { and adults }\end{array}$ \\
\hline \multicolumn{7}{|c|}{ Entire sampling area $\left(24\right.$ to $\left.29^{\circ} \mathrm{N}\right)$} \\
\hline$<50$ & $80836(100.0)$ & $670(100.0)$ & $0(0.0)$ & $0(0.0)$ & 0 & 0 \\
\hline $50-100$ & $43867(95.5)$ & $7724(99.1)$ & $1989(4.3)$ & $9(0.1)$ & 87 & 64 \\
\hline $100-150$ & $5420(98.7)$ & $2690(97.5)$ & $17(0.3)$ & $9(0.3)$ & 53 & 59 \\
\hline $150-200$ & $4373(91.5)$ & $2822(97.9)$ & $316(6.6)$ & $2(0.1)$ & 88 & 60 \\
\hline $200-300$ & $6584(98.0)$ & $1705(92.7)$ & $86(1.3)$ & $5(0.3)$ & 50 & 130 \\
\hline $300-500$ & $3548(85.6)$ & $473(30.5)$ & $502(12.1)$ & $482(31.1)$ & 93 & 593 \\
\hline $500-1000$ & $7797(96.5)$ & $1199(72.0)$ & $124(1.5)$ & $268(16.1)$ & 157 & 199 \\
\hline$>1000$ & $1455(65.1)$ & $356(28.4)$ & $451(20.2)$ & $277(22.1\}$ & 328 & 620 \\
\hline \multicolumn{7}{|c|}{$\begin{array}{l}\text { Punta Eugenia area }\left(27 \text { to } 29^{\circ} \mathrm{N}\right) \\
<50\end{array}$} \\
\hline $50-100$ & $60322(99.9)$ & 5095 (99.5) & $0(0.0)$ & $1(0.0)$ & 38 & 23 \\
\hline $\begin{array}{l}100-150 \\
150-200\end{array}$ & $14333(99.0)$ & $9962(98.0)$ & $62(0.4)$ & $19(0.2)$ & 78 & 184 \\
\hline $\begin{array}{l}200-300 \\
300-500\end{array}$ & $4035(98.7)$ & $1342(88.1)$ & $0(0.0)$ & $3(0.2)$ & 55 & 178 \\
\hline $\begin{array}{l}300-500 \\
500-1000\end{array}$ & & & & & & \\
\hline$>1000$ & $2803(88.0)$ & $248(16.2)$ & $73(2.3)$ & $279(18.1)$ & 304 & 1010 \\
\hline \multicolumn{7}{|c|}{$\begin{array}{l}\text { Bahia Magdalena area }\left(24 \text { to } 25^{\circ} \mathrm{N}\right) \\
<50\end{array}$} \\
\hline $\begin{array}{r}50-100 \\
100-150\end{array}$ & $36691(99.7)$ & $8717(99.7)$ & $95(0.3)$ & $0(0.0)$ & 0 & 28 \\
\hline $150-200$ & $7080 \quad(91.2)$ & $289(77.1)$ & $632(8.1)$ & $4(0.6)$ & 49 & 82 \\
\hline $200-300$ & $7464 \quad(97.6)$ & $494 \quad(74.9)$ & $119(1.6)$ & $3(0.8)$ & 61 & 163 \\
\hline $300-500$ & $766(32.3)$ & $18(0.6)$ & $1505(63.4)$ & $1398(4.3)$ & 103 & 1501 \\
\hline $500-1000$ & $3409(78.2)$ & $211(19.8)$ & $704(16.1)$ & $346(5.7)$ & 249 & 509 \\
\hline$>1000$ & $459(40.8)$ & $46(6.2)$ & 556 (49.5) & $171 \quad(9.7)$ & 109 & 528 \\
\hline
\end{tabular}



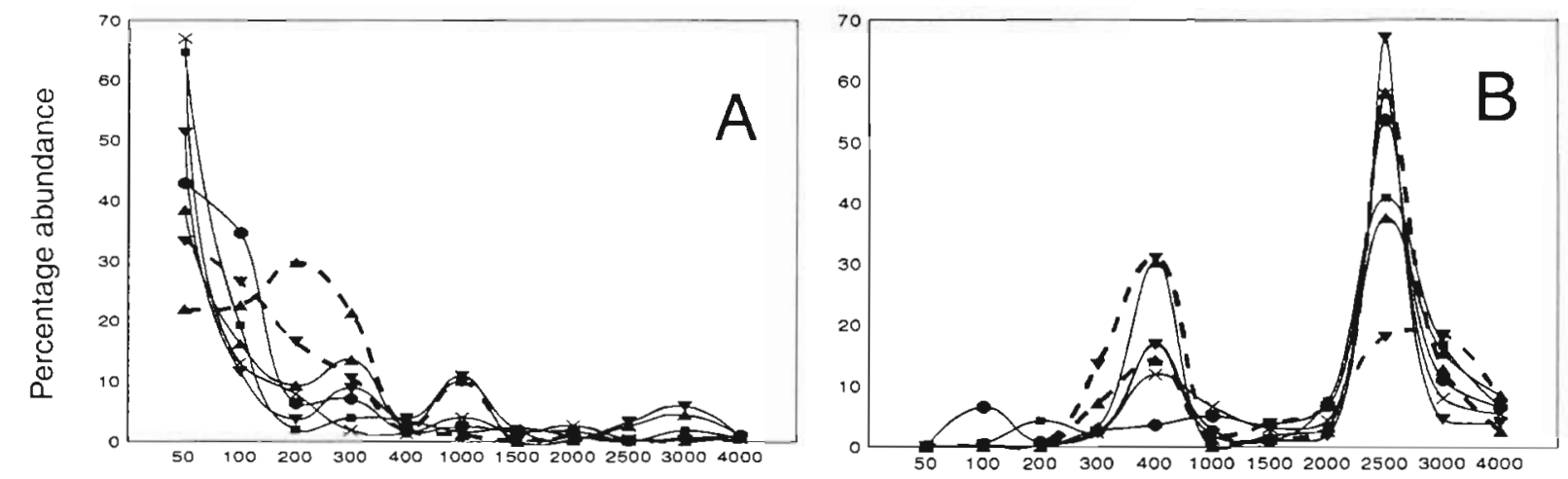

Station depth $(m)$

$\rightarrow$ Calyptopes

- Furciliae $\quad *$ Juveniles

$\rightarrow$ Females

- $=$-Reproductive females

* Males $\quad-\star-$ Reproductive males

Fig. 4. (A) Nyctiphanes simplex, (B) Euphausia eximia. Relative abundance (\%) of different stages expressed as a function of depth

variations throughout the year in its southern distribution near Bahia Magdalena (Fig. 5). Relatively low abundances for all stages of $N$. simplex were found in May 1986. Maximum abundances occurred during June 1986 when the strongest upwelling occurred and SST was between 15 and $19^{\circ} \mathrm{C}$. The larval abundance decreased to minimum values in November 1986 when there were stratified waters and an SST of 22 to $26^{\circ} \mathrm{C}$. Adults of N. simplex were not found during this month.
During July and October 1987, the most abundant stages were larvae and juveniles. In October 1987, a low abundance of adults was found at this latitude (Fig. 5). The maximum sizes were $16.5 \mathrm{~mm}$ and $17.1 \mathrm{~mm}$ for females and males during May and June 1986 (high intensities of upwelling). The border size between juveniles and immature females is difficult to discern. and so both were combined. The size at first maturity is approximately $7.5 \mathrm{~mm}$ for both sexes, however most of

Table 2. Nyctiphanes simplex and Euphausia eximia. Two-way ANOVA for abundance of different stages from population sampled in 1986 and 1987 in the Bahia Magdalena area (24 to $25^{\circ} \mathrm{N}$ ). Mean abundance (ind. $1000 \mathrm{~m}^{-3}$ ) is shown for each month and for inshore $(<200 \mathrm{~m})$ and offshore $(>200 \mathrm{~m})$ regions. Numbers of adults are separated by sex and reproductive condition.

Percentages of females with pouches and males with spermatophore (sperm.) are shown in parentheses. " $p<0.05 ; "{ }^{\prime}<0.01$

\begin{tabular}{|c|c|c|c|c|c|c|c|c|}
\hline & \multirow[t]{2}{*}{ Calyptopes } & \multirow[t]{2}{*}{ Furciliae } & \multirow[t]{2}{*}{ Juveniles } & \multirow{2}{*}{$\begin{array}{l}\text { Total } \\
\text { adults }\end{array}$} & \multicolumn{2}{|c|}{ Females } & \multicolumn{2}{|c|}{ Males } \\
\hline & & & & & Immature & With pouches & Immature & With sperm. \\
\hline \multicolumn{9}{|l|}{ N. simplex } \\
\hline Fisher value & 1.4 & 1.4 & $3.3^{\circ}$ & 1.0 & $19.9^{\bullet}$ & $17.0^{\circ}$ & $31.1^{\cdots}$ & $3.6^{\circ}$ \\
\hline May 1986 & 958.5 & 1440.2 & 189.8 & 1075.5 & 20.0 & $23.2(53.8)$ & 23.4 & $16.7 \quad(41.6)$ \\
\hline Jun & 218.7 & 1598.6 & 346.5 & 2518.2 & 136.7 & $475.3(77.6)$ & 163.8 & $126.6(43.6)$ \\
\hline Aug & 439.1 & 379.8 & 42.0 & 51.0 & 17.8 & $18.8(51.4)$ & 9.5 & $19.6(67.4)$ \\
\hline Nov & 94.0 & 82.0 & 62.8 & 8.5 & 1.8 & $4.7(72.3)$ & 3.8 & $3.1(44.9)$ \\
\hline Jul 1987 & 621.6 & 700.1 & 36.8 & 0.0 & 0.0 & $0.0(0.0)$ & 0.0 & $0.0(0.0)$ \\
\hline Oct & 201.3 & 243.4 & 116.6 & 178.0 & 66.2 & $22.2(25.1)$ & 30.3 & $26.2(47.1)$ \\
\hline Fisher value & $4.6^{\circ}$ & 0.2 & $4.6^{\circ}$ & 4.0 & $66.0^{\cdots}$ & $8.0^{\cdots}$ & $7.8 \cdots$ & 1.1 \\
\hline Inshore & 768.0 & 844.4 & 218.7 & 2133.0 & 102.9 & $263.0(71.9)$ & 31.7 & $85.2(72.9)$ \\
\hline Offshore & 249.1 & 667.1 & 102.1 & 45.7 & 11.9 & $15.6(56.7)$ & 8.1 & $12.4(60.5)$ \\
\hline \multicolumn{9}{|l|}{ E. eximia } \\
\hline Fisher value & 1.3 & 1.9 & 2.6 & 0.8 & $6.2 \cdots$ & $2.6 \cdots$ & 2.4 & $6.8 \cdots$ \\
\hline May 1986 & 38.7 & 234.3 & 205.4 & 72.1 & 6.6 & $5.3(44.5)$ & 6.5 & $5.1(44.0)$ \\
\hline Jun & 4.4 & 20.4 & 55.4 & 81.0 & 5.7 & $7.4(56.5)$ & 7.1 & $7.2(50.3)$ \\
\hline Aug & 21.8 & 80.7 & 36.4 & 34.8 & 6.1 & $5.8(48.7)$ & 6.3 & $7.8 \quad(55.3)$ \\
\hline Nov & 92.3 & 44.2 & 54.0 & 67.3 & 11.9 & $7.1\{37.4\}$ & 4.8 & $10.4(68.4)$ \\
\hline Jul 1987 & 0.0 & 14.8 & 8.0 & 24.0 & 5.9 & $6.8(53.5)$ & 4.6 & $6.5(58.6)$ \\
\hline Oct & 287.0 & 74.4 & 50.5 & 24.5 & 10.8 & $3.3(23.4)$ & 17.3 & $3.6(17.2)$ \\
\hline Fisher value & $2.4^{\circ}$ & 0.2 & 0.1 & 0.3 & $4.4^{\circ}$ & 0.6 & 0.4 & 2.4 \\
\hline Inshore & 50.8 & 40.2 & 40.8 & 63.5 & 5.3 & $4.9(48.0)$ & 4.9 & $4.9(50.0)$ \\
\hline Offshore & 122.5 & 87.4 & 63.7 & 50.5 & 9.1 & $5.9(39.3)$ & 6.7 & $7.0(51.1)$ \\
\hline
\end{tabular}




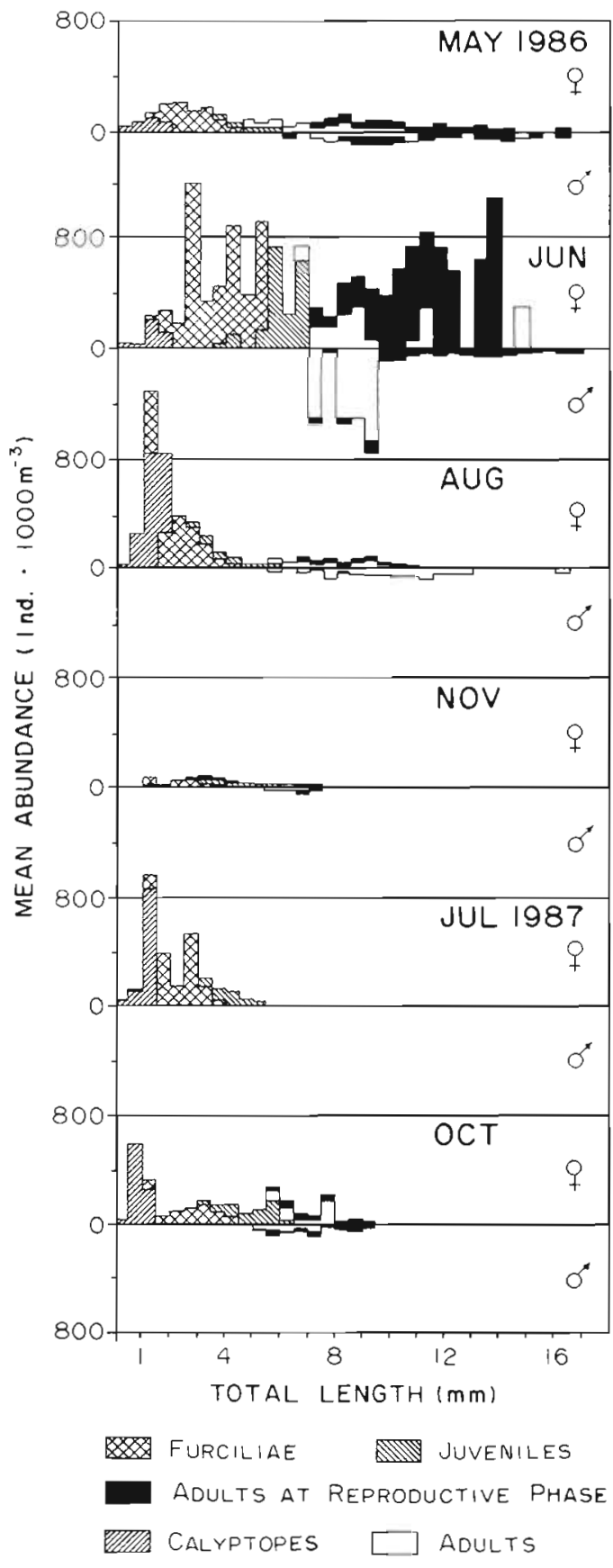

Fig. 5. Nyctiphanes simplex. Length-frequency histograms (ind. $1000 \mathrm{~m}^{-3}$ ) in samples from Bahia Magdalena (24 to $25^{\circ} \mathrm{N}$ ) during 1986 and 1987. Calyptopes, furciliae, and juveniles were not sexed. Non-reproductive and reproductive active females above the line and non-reproductive and reproductive active males below the line

the population showed maturity at $>8.5 \mathrm{~mm}$. The mean sizes of both sexes tend to decrease throughout the year (Table 3). Brinton \& Willie (1976) reported sizes for juveniles of 6 to $7 \mathrm{~mm}$ and for adults of 8 to $12 \mathrm{~mm}$, along the coast of California.

\begin{tabular}{|c|c|c|}
\hline 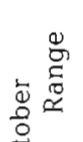 & 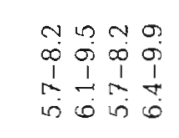 & 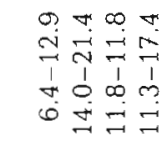 \\
\hline 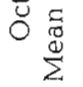 & 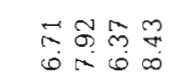 & 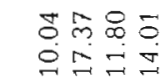 \\
\hline 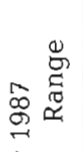 & & 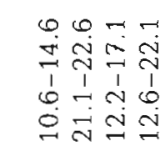 \\
\hline 文 & & 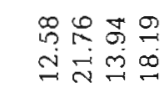 \\
\hline 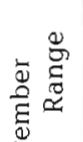 & 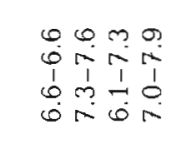 & 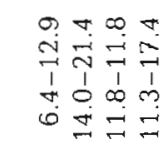 \\
\hline 完 & 草 & 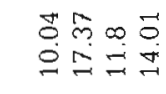 \\
\hline 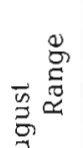 & 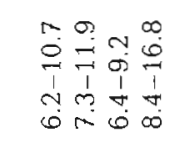 & 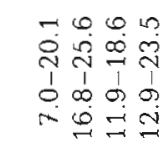 \\
\hline 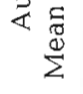 & 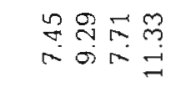 & 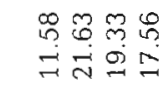 \\
\hline 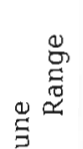 & 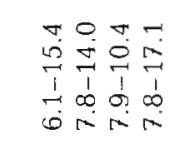 & 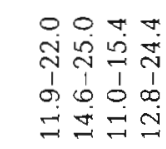 \\
\hline$\stackrel{\Xi}{\Xi}$ & 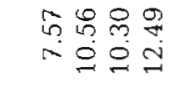 & 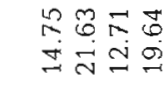 \\
\hline 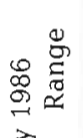 & 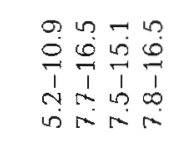 & 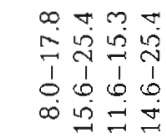 \\
\hline 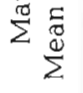 & 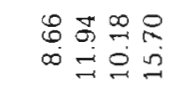 & 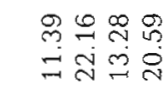 \\
\hline & 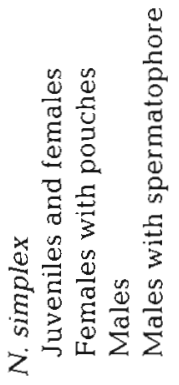 & 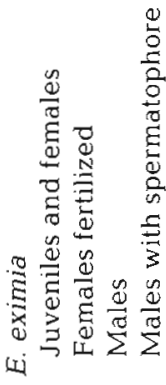 \\
\hline
\end{tabular}




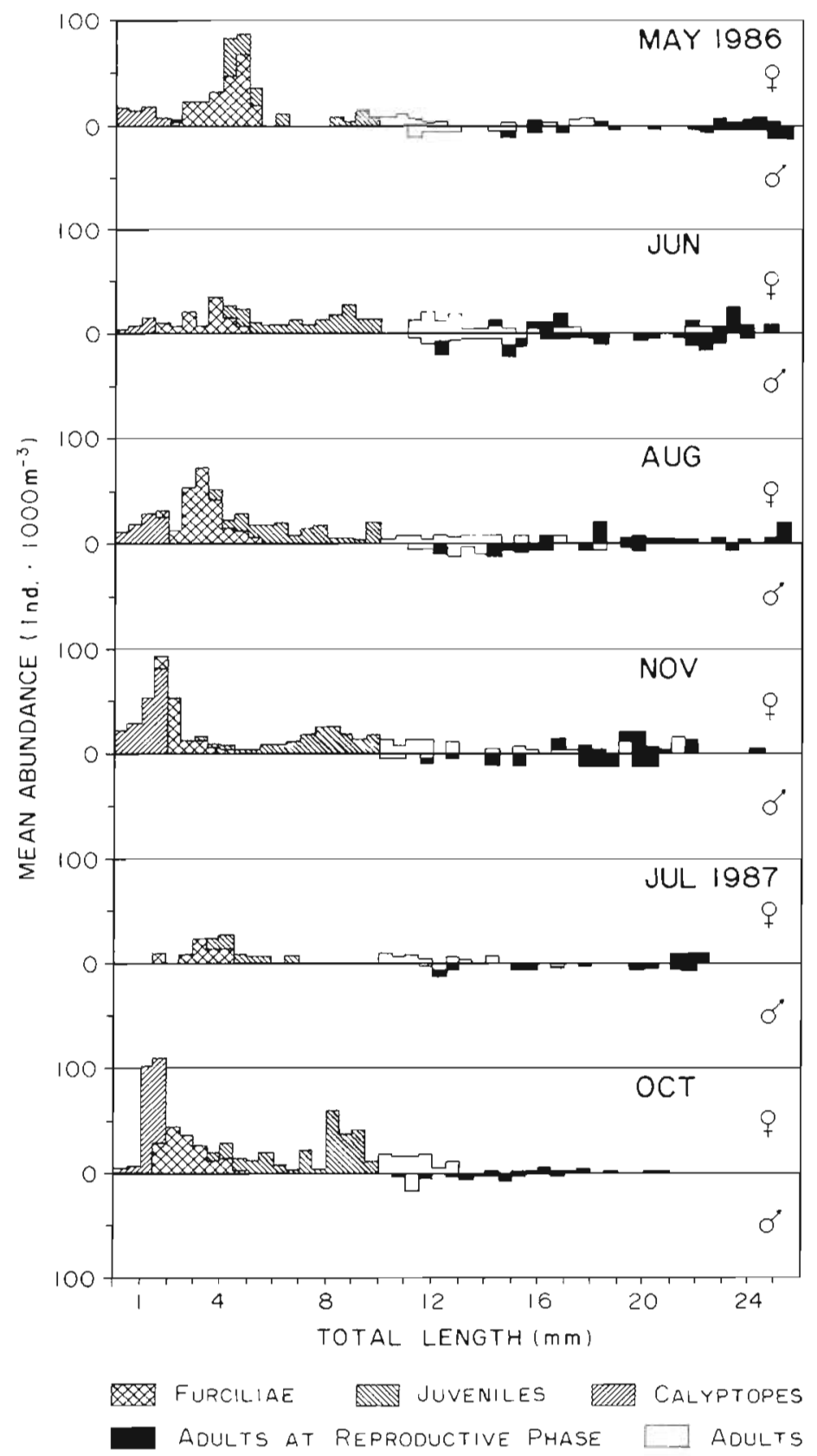

Fig. 6. Euphausia eximia. Length-frequency histograms (ind. $1000 \mathrm{~m}^{-3}$ ) in samples from Bahia Magdalena (24 to $25^{\circ} \mathrm{N}$ ) during 1986 and 1987. Calyptopes, furciliae, and juveniles were not sexed. Nonreproductive and reproductive active females above the line and non-reproductive and reproductive active males below the line

occurred during autumn when seasonal warming off the Pacific coast of Baja California occurred (November 1986, October 1987) (Fig. 6). The maximum sizes recorded were $25.6 \mathrm{~mm}$ and $25.4 \mathrm{~mm}$ for females and males during the May, June, and August 1986 surveys and $22.6 \mathrm{~mm}$ for females and $22.2 \mathrm{~mm}$ for males in 1987 . The size at first maturity is reached at $14 \mathrm{~mm}$ for females and $11.3 \mathrm{~mm}$ for males (Table 3). Brinton \& Willie (1976) considered adults ranged between 15 and $23 \mathrm{~mm}$, thus our results include adults both smaller and larger, 12.5 to $25.6 \mathrm{~mm}$, than reported by those authors. Size varied significantly in adults of both species as a function of sex and inshore-offshore region. Inshore populations were composed of smaller individuals than offshore populations (Table 4, 2-way ANOVA, $p<0.01$ ).

In order to compare data of total length of Nyctiphanes simplex reported by Lavaniegos (1992), who measured from the tip of the rostrum to the end of the telson $\left(T L_{w}\right)$, with our data, which did not include the rostrum $\left(T L_{n r}\right)$, 2 linear regressions $(n=100)$ were calculated:

$$
\begin{aligned}
& T L_{\mathrm{wr}}=0.2146+1.0199 T L_{\mathrm{nr}}(\mathrm{r}=0.999) \\
& T L_{\mathrm{nr}}=-0.1991+0.9790 T L_{\mathrm{wr}}(\mathrm{r}=0.999)
\end{aligned}
$$

Using the parameters of von Bertalanffy ( $L_{\text {inf }}$ = 18.6, $K=0.010 \mathrm{~d}^{-1}$ ) for Nyctiphanes simplex obtained by Lavaniegos (1992), the age at first maturity $\left(T L_{\mathrm{nr}}=7.5 \mathrm{~mm}\right)$ for our data $\left(T L_{\mathrm{wr}}=\right.$ 7.86) was about $63 \mathrm{~d}$. The maximum size $\left(T L_{n r}=\right.$ $16.5_{i} T L_{\mathrm{wr}}=17.04$ females with pouches, and $T L_{\mathrm{nr}}=17.1_{\mathrm{i}} T L_{\mathrm{wr}}=17.65$ males) would require 243 and $289 \mathrm{~d}$. However, the mean life span of the most of the adults would be about 180 to $227 \mathrm{~d}$.

For Euphausia eximia, parameters of growth were not estimated. Discrete cohorts were difficult to follow because of the complex sizefrequency distributions and gaps in the timeseries for this species. The extended spawning season of E. eximia and variability of catch of adults in the reproductive phase made interpretation of growth difficult. Nevertheless, using methods similar to Barange \& Stuart (1991), tentative growth rates could be estimated for May to November 1986 using the probability

For Euphausia eximia, the population structure showed no important variations in abundance through the year near Bahia Magdalena. Calyptopis larvae were present for all months studied indicating continuous recruitment. That reproduction occurred continuously was evidenced by calyptopes and adults in the reproductive phase. The main reproductive activity paper method (Ritz \& Hosie 1982). Identification of the modal frequency suggests an initial growth rate of $0.208 \mathrm{~mm} \mathrm{~d}^{-1}$ for larvae, followed by a lower rate, $0.091 \mathrm{~mm} \mathrm{~d}^{-1}$, for juveniles, and decreasing further to $0.036 \mathrm{~mm} \mathrm{~d}^{-1}$ in adults. The largest adult so far collected $(27 \mathrm{~mm})$ was estimated, using the calculated growth curve, to be approximately $548 \mathrm{~d}$ old $(18 \mathrm{mo}$ ). 
Table 4. Nyctiphanes simplex and Euphausia eximia. Two-way ANOVA for total length of different sex of adults from population sampled in 1986 and 1987 in the Bahia Magdalena area ( 24 to $25^{\circ} \mathrm{N}$ ). Average of the total length $(\mathrm{mm})$ in the inshore $(<200 \mathrm{~m})$ and offshore $(>200 \mathrm{~m})$ regions are shown in parentheses. With sperm.: with spermatophore. $p<0.05 ; \cdots p<0.01$

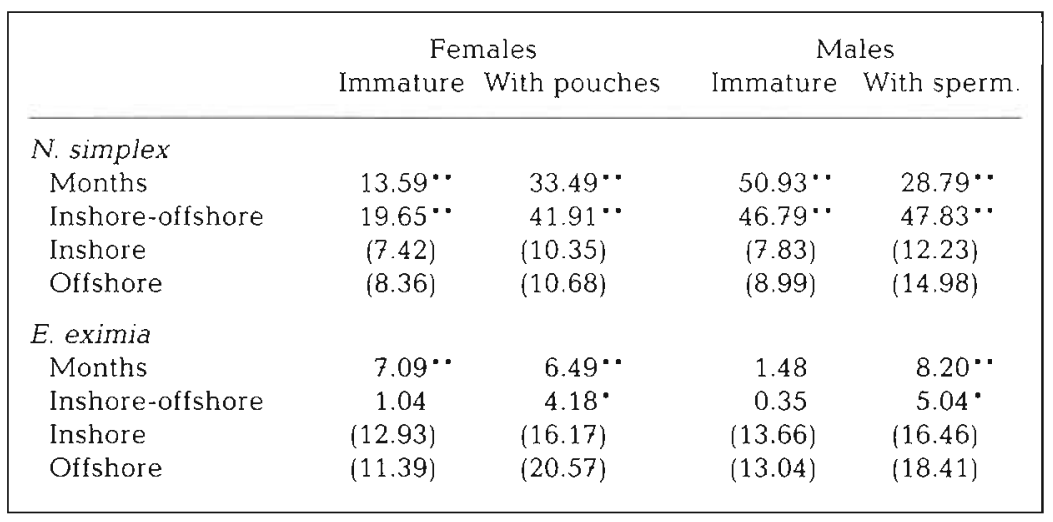

However, the majority of adults would be approximately $326 \mathrm{~d}$ old $(11 \mathrm{mo})$. The age of first maturity $(15 \mathrm{~mm})$ could be reached at about $215 \mathrm{~d}$

\section{Maturity of females}

Using the maturity stages proposed by Mauchline (1968), at least 2 different groups were detected in
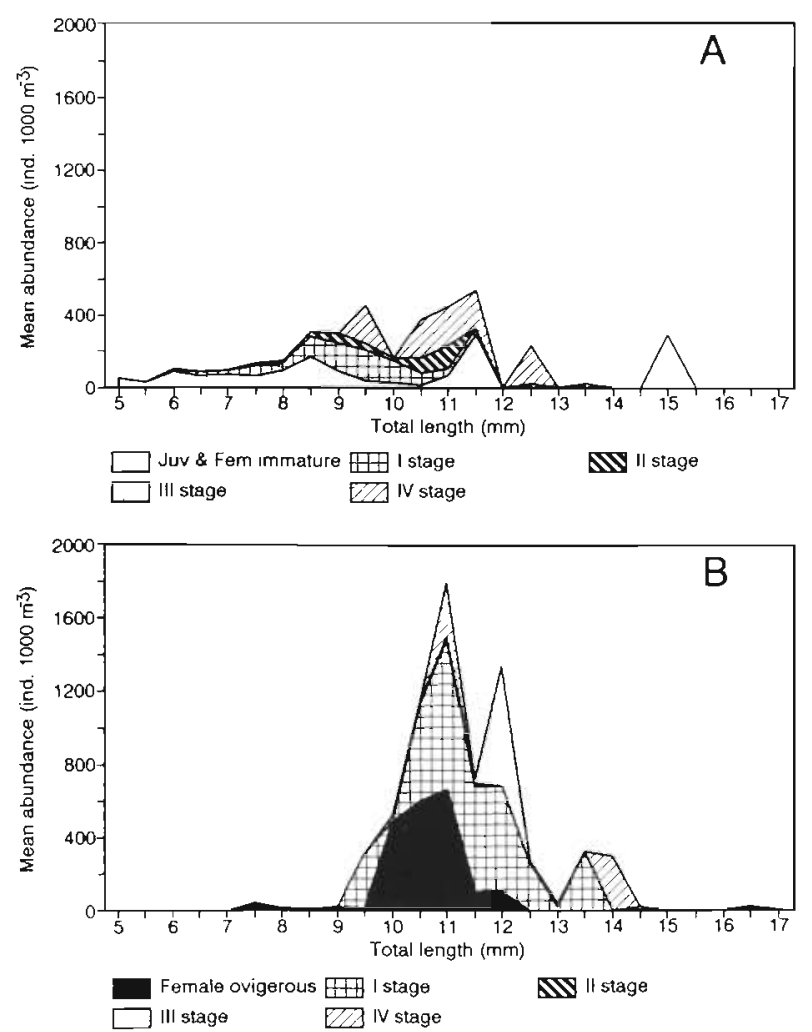

Nyctiphanes simplex. One, before the ovigerous sac develops, consisted of 4 maturity stages (Fig. 7A). The other, after the ovigerous sac was formed and the eggs hatched, was evidenced by a hollow space between the last thoracopods and the first pair of pleopods (Lavaniegos 1994), and could include 4 maturity stages also. The minimum size of the fast maturation of the species (Fig. 7B). Small females were recorded in May. Ovigerous females were observed in June and their size decreased in the second half of the year (Table 5). Fig. 7 shows the majority of ovaries examined contained a large range of sizes of eggs of different stages, suggesting continuous maturation of the ovary and the production of multiple broods. Very few undeveloped or spent ovaries were found, indicating that the ovaries do not regress to a resting stage. Euphausia eximia mature at about $15 \mathrm{~mm}$ and showed overlap between size and maturity stage interpreted as continuous breeding of the females. The advanced stages occurred during autumn (Fig. 7C. Table 5).
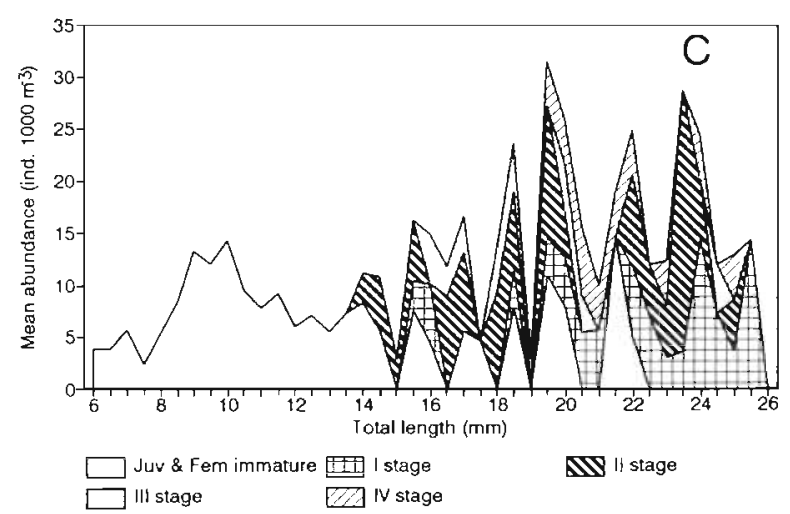

AN it stage first stage is $6 \mathrm{~mm}$, close to the mean size of juveniles and suggesting a

Fig. 7. Nyctiphanes simplex and Euphausia eximia. Length-frequency histograms (ind, $1000 \mathrm{~m}^{-3}$ ) of females of (A) pre-ovigerous $N$. simplex, (B) post-ovigerous stage $N$ simplex and (C) E. eximia in samples from the west coast of Baja California ( 24 to $25^{\circ} \mathrm{N}$ ) during 1986 and 1987 
Table 5. Nyctiphanes simplex and Euphausia eximia. Abundance (ind. $1000 \mathrm{~m}^{-3}$ ) and mean total length in mm (MTL) of females according to maturity of eggs in the ovaries (adapted from Mauchline 1968) in the Bahia Magdalena sampling area (24 to $25^{\circ} \mathrm{N}$ ) from May 1986 to October 1987

\begin{tabular}{|c|c|c|c|c|c|c|c|c|c|c|c|c|}
\hline & \multicolumn{2}{|c|}{$\begin{array}{c}\text { May } 1986 \\
\text { Abund. MTL }\end{array}$} & \multicolumn{2}{|c|}{ June } & \multicolumn{2}{|c|}{ August } & \multicolumn{2}{|c|}{ November } & \multicolumn{2}{|c|}{ July 1989} & \multicolumn{2}{|c|}{$\begin{array}{c}\text { October } \\
\text { Abund. MTL }\end{array}$} \\
\hline \multicolumn{13}{|l|}{ N. simplex } \\
\hline Immature & 31.2 & 7.3 & 136.7 & 7.6 & 17.8 & 7.4 & 1.8 & 6.6 & & & 66.2 & 6.2 \\
\hline Stage I & 26.1 & 9.5 & 213.6 & 9.4 & 22.1 & 9.0 & & & & & 23.6 & 7.4 \\
\hline Stage II & 13.9 & 11.3 & 216.0 & 10.9 & 27.1 & 9.1 & 3.1 & 7.4 & & & 16.9 & 8.8 \\
\hline Stage III & 26.5 & 12.2 & 216.0 & 11.1 & 16.5 & 9.5 & 6.3 & 7.5 & & & 16.9 & 9.2 \\
\hline Stage IV & 26.4 & 12.2 & 216.0 & 11.1 & 7.6 & 9.5 & & & & & & \\
\hline Female ovigerous & & & 462.9 & 11.3 & 6.9 & 10.4 & & & & & 23.6 & 8.8 \\
\hline Stage I & & & 929.4 & 11.6 & & & & & & & 20.2 & 8.8 \\
\hline Stage II & & & & & & & & & & & & \\
\hline Stage II & & & 836.6 & 12.7 & & & & & & & & \\
\hline Stage IV & & & 1189.3 & 12.7 & & & & & & & & \\
\hline \multicolumn{13}{|l|}{ E. eximia } \\
\hline Immature & 6.6 & 11.4 & 5.7 & 14.8 & 6.1 & 11.6 & 11.9 & 11.4 & 5.9 & 12.6 & 10.8 & 10.0 \\
\hline Stage I & 5.0 & 23.8 & & & 8.4 & 22.8 & 4.4 & 20.1 & 6.8 & 21.8 & 3.9 & 17.8 \\
\hline Stage II & 5.9 & 16.8 & 7.6 & 22.0 & 6.0 & 19.5 & 11.1 & 19.5 & & & 2.9 & 14.6 \\
\hline Stage III & 4.9 & 16.2 & 4.4 & 20.9 & 4.8 & 17.9 & 3.2 & 17.8 & & & & \\
\hline Stage IV & & & & & 4.7 & 21.7 & & & & & & \\
\hline
\end{tabular}

\section{DISCUSSION}

\section{Distribution patterns}

Seasonal trends in hydrography along the west coast of Baja California have been described by Reid et al. (1958), Wyrtki (1965, 1967), Roden (1971), Bakun \& Nelson (1977), McLain et al. (1985), and Lynn \& Simpson (1987, 1990). These can be summarized as follows: during the spring, the California Current has an influence all along the coast. Our data show that water $<18^{\circ} \mathrm{C}$ occurs along the coast with the most intense upwelling occurring in May and June. Seasonal variations of the SST show lower values between January and June. In summer and autumn, this area is influenced by the countercurrent, increasing the SST in spite of significant offshore Ekman transport (Huyer 1983). Strong alongshore temperature gradients occur south of this area where the upwelling decreases in intensity (October to December). Seasonal differences along the coast yield maximum upwelling intensities from March to June and seasonal warming from July to November (Bakun \& Nelson 1977. Huyer 1983). This seasonality has an important influence on the latitudinal distribution patterns of Nyctiphanes simplex, particularly near Bahia Magdalena. There the abundance decreased during summer and autumn, when warmer water moved northward, reaching lowest abundance in November. Lavaniegos (1994) found recruitment to occur year round, most intensely in fall and winter. I found the most intensive recruitment was in spring. The population of Euphausia eximia seems not to be influenced by seasonal environmental variations in Bahia Magdalena as indicated by the species' continuous recruitment all year.

The offshore-inshore distribution patterns of $N_{y c t i-}$ phanes simplex and Euphausia eximia remain fairly constant throughout the season. All stages of $N$. simplex showed high densities along most of the coastal and shelf regions during active upwelling conditions. They were not displaced offshore by the associated Ekman surface transport (i.e. May and June 1986). This suggests that maintenance strategies are involved, as has been found for $N$. simplex in Bahia Sebastián Vizcaíno $\left(28^{\circ} \mathrm{N}\right.$ ) on the west coast of Baja California (Lavaniegos 1993, 1994). Larval stages could be trapped in the central eddy of the bay until the end of larval development (Hewitt 1981, Lavaniegos 1994). The vertical migratory behavior of postlarvae (Brinton 1967) may help them avoid offshore flow on the surface like other zooplankton species in areas dominated by coastal upwelling and complex advective processes in the California Current System (Brinton 1976, Peterson et al. 1979). At Bahia Magdalena upwelling indices lower than Punta Eugenia could help keep all life stages close to the coast.

Recent studies done in the Benguela Current System propose a 1-cell cross-shelf circulation model to explain how Euphausia lucens can remain in high concentrations within the southern Benguela shelf regions (Pillar et al. 1989). Barange \& Stuart (1991), Barange \& Boyd (1992), and Barange \& Pillar (1992), in suggesting a maintenance mechanism for Nyctiphanes capensis and E. hanseni, proposed a 2-celled circu- 
lation scheme in the northern Benguela, yielding a different maintenance mechanism than that of the southern Benguela region.

We cannot propose a mechanism of maintenance because we did not use a multiple closing-opening net to map vertical and horizontal distribution. In addition, along the southern Baja California peninsula there are few direct current observations and sparse hydrographic measurements. Understanding of the region is at best sketchy. Nyctiphanes simplex does have a constant high abundance near shore, especially in regions with changes in coastline orientation, like Bahia Sebastián Vizcaino, Punta Abreojos, and Bahia Magdalena. These seem to play a significant role in reducing upwelling and eddy formation. This suggests this species develops maintenance strategies, as an adaptation to the upwelling conditions, that would reduce advective losses. The population structure seems to be a function of station depth or distance from shore (only the largest adults inhabit offshore region). Significant differences in abundance of $N$. simplex between inshore and offshore support this hypothesis. Walsh et al. (1977) observed southeastward surface currents in spring, with a vertical shear in the along-shore flow. They observed offshore flow in the surface layer, an onshore flow at mid-depth and near the bottom, and some northward flow near the bottom. This could suggest a mechanism of maintenance for $N$. simplex. Our study found the largest individuals offshore. These results are opposite to these obtained by Barange \& Stuart (1991) where the largest individuals of $N$. capensis were found inshore. Barange \& Boyd (1992) postulated the unusually high abundance of large adult $N$. capensis in the region 22 to $23^{\circ} \mathrm{S}$ in the Benguela Current System resulted from a combination of a semi-enclosed circulation that would reduce advective losses and give relatively good concentrations of food and stable water. Similar conclusions were proposed by Lavaniegos (1993) for $N$. simplex in the region of Bahia Vizcaíno.

In general, in the oceanic zone of the California Current System, a southward flow, indicated by geostrophic flow, predominates almost the entire year (Wyllie 1966). However, the coastal environment is characterized by a stronger horizontal and vertical circulation system little known in the southern part of the California Current System (Huyer 1983).

Euphausia eximia showed an inshore-offshore pattern featured by 2 peaks of high abundance densities, one at stations of about $400 \mathrm{~m}$ and a second offshore at more than $2500 \mathrm{~m}$ depth. Negative wind stress curl (Ekman convergence) is characteristic of the offshore region. From Punta Baja to Punta Eugenia, the convergent region reaches to the coast (Bakun \& Nelson 1977 , Huyer 1983). This process could be responsible for the abundance peak close to the break-shelf along the west coast of Baja California.

We note that important monthly differences between males and females of both species were observed. The male Nyctiphanes simplex were larger than females while the converse was true for Euphausia eximia. Similar size/sex relations were reported for $N$. capensis and $E$. hanseni in the Benguela Current (Barange \& Stuart 1991). This suggests different growth rates for each sex and different strategies for reproduction in each species.

The population of Nyctiphanes simplex in the southern area (Bahia Magdalena) varied in abundance throughout year as a function of the upwelling intensities and SST fluctuations. In the southern part of the west coast of Baja California after August the temperature increased and the water column became stratified (Gómez 1990). The great variations in the environmental conditions in this region induce strong seasonal variations in the population structure of $N$. simplex. This northward movement becomes particularly intense during years recognized as El Niño-Southern Oscillation (ENSO) events. Three extensions of $N$. simplex beyond its usual distribution range have been reported along central and northern California during 1958 , 1977 to 1978 and 1982 to 1983 during unusually warm conditions in the California Current (Brinton 1981, Brinton \& Reid 1986, Brodeur 1986).

The offshore reproduction areas of Euphausia eximia were constant during all study periods. This suggests less dependence on the upwelling environment and a continuous reproduction and recruitment. The maximum number of organisms was found during summer and autumn. Brinton \& Willie (1976) reported a maximum spread along the California coast from October 1953 to January 1954 and October to December 1954 This species has been considered an endemic marginal Eastern tropical Pacific proliferator species (Brinton 1979) and, in this study, as a species well adapted to offshore regions having low secondary production (zooplankton biomass) and apparently without strong seasonality in the study area. A marked increase in the proportion of females carrying ripe eggs and of calyptopis larvae with distance offshore was observed (Table 2), despite a low concentration of zooplankton biomass in the offshore regions. The feeding habits of this species are as yet unknown. Reproduction in warmer offshore water may facilitate faster development.

\section{Temporal changes in population structure in Bahia Magdalena}

Seasonal trends found in Bahia Magdalena indicate that each species attains a maximum size in a differ- 
ent month, Nyctiphanes simplex during spring and summer and Euphausia eximia during summer and autumn, coinciding with their maximum densities. A larger number of fertilized female (>21 mm) $E$. eximia were present in all samples suggesting continuous spawning throughout the year. The presence of $N$. simplex females bearing brood pouches only during May to August 1986 suggests seasonal reproduction at this latitude $\left(24\right.$ to $25^{\circ} \mathrm{N}$ ). Lavaniegos (1993) reported the seasonal abundance of $N$. simplex between Punta Eugenia and Punta Abreojos during 1966, concluding there was continuous recruitment throughout the year. Judging by the distribution and abundance of calyptopes, the reproduction was more intense during winter (January to February) with temperatures (10 m) between 16 and $19^{\circ} \mathrm{C}$. This temperature range was recorded during May 1986 only along the peninsula and, during 1987, only along the northern part coinciding with a large abundance of larvae (including furciliae). In the Bahia Magdalena region, the $N$. simplex abundance showed a decreasing trend throughout year. This trend is considered a feature of the region.

\section{Growth rates in Bahia Magdalena}

Lavaniegos (1992) estimated the growth rates of Nyctiphanes simplex larvae based on the von Bertalanffy equation under laboratory conditions and proposed that the maximum life span is 7 to $8 \mathrm{mo}$. A duration of 4 to $5 \mathrm{wk}$ for the larval phase was predicted by the equation under optimal feeding conditions (from pseudometanauplius to first juvenile). Using a growth curve $\left(K=0.001 \mathrm{~d}^{-1} ; L_{\mathrm{nf}}=18.6 \mathrm{~mm}\right)$, I estimated that a maximum size of $17 \mathrm{~mm}$ (measured from the rostrum to the end of telson) would require $245 \mathrm{~d}$. Therefore, at most, the adult phase would last 6 to 7 mo. We estimated the age to maximum total length to be about $9 \mathrm{mo}$. The life span is generally less for most of the population. Growth rates for adults of Nyctiphanes capensis in the Benguela Current range between 0.003 and $0.063 \mathrm{~mm} \mathrm{~d}^{-1}$, obtained by the probability paper method (Barange \& Stuart 1991).

During the period studied, female Nyctiphanes simplex in different maturation stages, identified according to the criteria of Hosie \& Ritz (1983), showed a continuous maturation of the ovaries, hence multiple releases of ova, as evidenced by the presence of more than 1 developing ova stage in females with pouches (several maturity stages). Similar conclusions were proposed by Stuart \& Nicol (1986) for N. capensis, Euphausia lucens, and E. hanseni, and Pillar \& Stuart (1989), Stuart (1992) for E. lucens. According to Gendron (1992), females of $N$. simplex in the Gulf of California have between 20 and 70 eggs per egg sac and the number is a function of the total length (9 to $13 \mathrm{~mm}$ ). Barange \& Stuart (1991) reported that $N$. capensis has between 50 and 180 eggs in the brood pouch of 12 to $21 \mathrm{~mm}$ females. It is possible that $N$. simplex has a faster growth rate than other California Current euphausiids like Nematoscelis difficilis. This suggests a major reproductive potential. In the California Current, a temperate euphausiid, E. pacifica, lives for about 1 yr and attains a maximum size of 22 to $24 \mathrm{~mm}$ total length (Smiles \& Pearcy 1971). N. simplex might complete its life history in less than 1 yr. Barange \& Stuart (1991) proposed the $N$. capensis and E. hanseni adult life span is approximately 6 mo. In our work the life span estimated for $N$. simplex was about 6 to 7.5 mo. Lindley (1982) concluded that 3 or 4 cohorts of Nyctiphanes couchi were spawned in each year in the North Atlantic, where temperatures varied between 7 and $10^{\circ} \mathrm{C}$, and their maximum life span was probably greater than $1 \mathrm{yr}$, although maturation may be attained in less than 1 yr. For a subtropical species like $N$. simplex, living in SST between 16 and $28^{\circ} \mathrm{C}$, development and life span must be shorter.

Euphausia eximia apparently could complete its life history in about $18 \mathrm{mo}$. The longevity and age at first maturity of this species has been unknown. The growth rates obtained in my work are higher than those obtained for E. pacifica $\left(0.065 \mathrm{~mm} \mathrm{~d}^{-1}\right)$ (Smiles \& Pearcy 1971) in the California Current, E. lucens $\left(0.131 \mathrm{~mm} \mathrm{~d}^{-1}\right.$ larvae, $0.047 \mathrm{~mm} \mathrm{~d}^{-1}$ juveniles, $0.026 \mathrm{~mm}$ $\mathrm{d}^{-1}$ adults) (Pillar \& Stuart 1989) in the Benguela Current, and lower than that obtained for $E$. hanseni $\left(0.77\right.$ to $0.83 \mathrm{~mm} \mathrm{~d}^{-1}$ ) in the Benguela Current (Barange \& Stuart 1991).

\section{Reproductive potential}

The constant presence of ripe females and males with a spermatophore of Nyctiphanes simplex suggests that this species has multiple spawning during its lifetime. Observation of females with ovigerous sac and internal eggs in the thorax provides evidence to suggest multiple releases of ova. A low frequency of spawning is evidenced by the presence of more than 1 stage of development in the majority of ovaries examined. In the North Atlantic, N. couchi spawned over a prolonged breeding season, giving rise to a complex of cohorts with overlapping size ranges (Lindley 1982). Barange \& Stuart (1991) estimated that multiple spawning of $N$. capensis took place throughout the year and that adults should have a life span of 6 to 7 mo. Hosie \& Ritz (1983) concluded that $N$, australis has continuous maturation of the ovaries, hence multiple releases of ova. These same authors reported continuous maturation of ovigerous females of $N$. australis 
capable of releasing 1100 eggs in a lifetime. $N$. simplex has about 20 to 60 eggs and/or metanauplii per egg sac with the number of eggs a function of the total length (Gendron 1992). Considering the presence of more than 1 maturity stage of this species, production of eggs could be similar to that of $N$. australis.

Reproduction of Euphausia eximia involves release of its eggs in the sea. This implies this species has a high fecundity. Eggs of this species are difficult to identify under natural conditions. Roger (1976) reported that reproduction in tropical euphausiids was nearly a continuous process. The production of multiple broods also shows a high fecundity.

The differences of habitat, mainly inshore-offshore of both euphausiid species off the west coast of the Baja California upwelling system, allow the maintenance of high densities of euphausiids through the year. Large environmental variations along the coast have an important influence on the population of Nyctiphanes simplex, especially their southern distribution. Several strategies, such as high variability of developmental pathways in the furcilia stages (Lavaniegos 1992, 1993, Gómez in press), their continuous maturation, and their long reproductive life compared with life span, could be of great use in inshore waters. The offshore region is more stable and has less influence on the population dynamics of Euphausia eximia. The combined effects of a protracted spawning season, particularly in the offshore region, accompanied by multiple spawning would enable E. eximia to maintain an important part of their population in low productive offshore waters. Future studies aimed at defining the biology and the trophic status of these abundant euphausiids in the southern part of the California Current system should be done.

Acknowledgements. Thanks to Dr Edward Brinton, Scripps Institution Oceanography, for advice for my M.Sc. thesis, to Dr Bertha Lavaniegos, Centro de Investigaciones Biológicas del Noroeste, for her important and critical suggestions to the original manuscript, to M.Sc. José Luis Castro Ortíz for his help with the estimation of the growth parameter and to Dr Ellis Glazier for his editorial help with the English text. This research was supported by funds provided by the Direccion de Estudios de Posgrado e Investigación (DEPI 903361, DEPI 931318) and by the Consejo Nacional de Ciencia y Tecnología (CONACYT D112-904620). The author was supported by COFAA-IPN fellowships.

\section{LITERATURE CITED}

Anonymous (1990). Data base of upwelling index and sea surface temperature off Eastern Pacific Tropical, Northern Hemisphere. 1946-1990. Pacific Fisheries Environmental Group (PFEG). SWFC, NOAA, Monterey, CA

Bailey, K. M., Francis, R. C., Stevens, P. R. (1982). The life his- tory and fishery of Pacific whiting Merluccius productus Calif, coop. ocean. Fish. Invest. Rep. 23: 81-98

Bakun, A., Nelson, C. S. (1977). Climatology of upwelling related processes off Baja California. Calif. coop. ocean. Fish. Invest. Rep. 19: 107-127

Barange, M., Boyd, A. J. (1992). Life history, circulation and maintenance of Nyctiphanes capensis (Euphausiacea) in the northern Benguela upwelling system. In: Payne, A. 1. L., Brink, K. H., Mann, K. H., Hilborn, R. (eds.) Benguela trophic functioning. S. Afr. J. mar. Sci. 12: p. 95-106

Barange, M., Pillar, S. C. (1992). Cross-shelf circulation, zonation and maintenance mechanisms of Nyctiphanes capensis and Euphausia hanseni (Euphausiacea) in the northern Benguela upwelling system. Cont. Shelf Res. 12 $1027-1042$

Barange, M., Stuart, V. (1991). Distribution patterns, abundance and population dynamics of the euphausiids Nyctiphanes capensis and Euphausia hanseni in the northern Benguela upwelling system. Mar. Biol. 109: 93-101

Beers, J. R. (1976). Volumetric methods. In: Steedmann, H. F. (ed.) Zooplankton fixation and preservation, Monographs on oceanographic methodology, Vol IV. UNESCO, Paris, p. $54-60$

Boden, B. P. (1951). The egg and larval stages of Nyctiphanes simplex a euphausiid crustacean from California. Proc. zool. Soc. Lond. 121 (3): 575-527

Brinton, E. (1960). Changes in the distribution of euphausiid crustaceans in the region of California Current. Calif. coop. ocean. Fish. Invest. Rep. 7: 137-146

Brinton, E. (1962). The distribution of Pacific euphausids. Bull. Scripps Inst. Oceanogr. 8: 51-270

Brinton, E. (1967). Vertical migration and avoidance capability of euphausiids in the California Current. Limnol. Oceanogr. 12: 451-483

Brinton, E. (1976). Population biology of Euphausia pacifica off southern California. Fish. Bull. U.S. 74: 733-762

Brinton, E. (1978). Observations of spermatophores attached of pleopods of preserved male euphausiids. Crustaceana 35: $241-249$

Brinton, E. (1979). Parameters relating to the distribution of planktonic organisms, especially euphausiids in the Eastern Tropical Pacific. Prog. Oceanogr 8: 125-189

Brinton, E. (1981). Euphausiid distributions in the California Current during the warm winter-spring of $1977-78$, in the context of a 1949-1966 time series. Calif. coop. ocean. Fish. Invest. Rep. 22: 135-154

Brinton, E., Reid, J. L. (1986). On the effect of interannual variations in circulation and temperature upon euphausiids of California Currents. In: Pierrot-Bults, Van der Spoel, Zahuranec, Johnson (eds.) Pelagic biogeography. UNESCO Tech. Pap. 49: 25-34

Brinton, E., Townsend, A. W. (1980). Euphausiids in the Gulf of California, the 1957 cruises. Calif. coop. ocean. Fish. Invest. Rep. 21: 211-236

Brinton, E., Willie, J. G. (1976). Distributional atlas of euphausiid growth stages off southern California, 1953 through 1966. Calif. coop ocean. Fish. Invest. Atlas 24: $1-289$

Brodeur, R. D. (1986). Northward displacement of the euphausiid Nyctiphanes simplex Hansen to Oregon and Washington waters following the El Nino event of 1982-83. J. crust. Biol. 6: 686-692

Caraveo, P. J. (1991). Hábitos alimenticios de la pierna (Caulolatilus princeps) (Jenyns, 1842) en la Bahía de La Paz, B.C.S., México. Degree thesis, Universidad Autónoma de Baja California Sur, La Paz

Gendron, D. (1990). Relación entre la abundancia de eu- 
faúsidos y de ballenas azules (Balaenoptera musculus) en el Golfo de California. M.Sc. thesis, Centro Interdisciplinario de Ciencias Marinas, Instituto Politécnico Nacional, La Paz

Gendron, D. (1992). Population structure of daytime surface swarms of Nyctiphanes simplex (Crustacea: Euphausiacea) in the Gulf of California, Mexico. Mar. Ecol Prog. Ser. 87: $1-6$

Gómez, G. J. (1990). Variación de la distribución y abundancia de los estadios planctónicos de Pleuroncodes planipes (Crustacea: Galatheidae) en la costa occidental de Baja California Sur, México (1986). Degree thesis, Universidad Autónoma de Baja California Sur, La Paz

Gómez, G. J. (1992). Efecto de las condiciones ambientales sobre la abundancia de las poblaciones de eufáusidos (Crustacea) en la costa occidental de Baja California, durante mayo de 1986, julio de 1987 y 1988 . M.Sc. thesis, Centro Interdisciplinario de Ciencias Marinas, Instituto Politécnico Nacional, La Paz

Gómez, G. J. (in press). Ecology of early larval development of Nyctiphanes simplex Hansen (Euphausiacea) of the west coast Baja California, Mexico. Bull. mar. Sci.

Gómez, G. J., Hernández, T S. (in press). Euphausiacea and Copepoda of the oceanic front off Cabo San Lucas B.C.S. Mexico, during August 1988. Revta Biol. trop

Hewitt, R. (1981). Eddies and speciation in the California Current. Calif. coop. ocean. Fish. Invest. Rep. 22: 96-98

Hosie, G. W, Ritz, D. A. (1983). Contribution of molting and eggs to secondary production in Nyctiphanes australis (Crustacea: Euphausiacea). Mar. Biol. 77: 215-220

Huyer, A. (1983). Coastal upwelling in the California Current System. Prog. Oceanogr. 12: 259-284

Knight, M. D. (1980). Larval development of Euphausia eximia (Crustacea: Euphausiacea) with notes on its vertical distribution and morphological divergence between populations. Fish. Bull. U.S. 78: 313-335

Lavaniegos, B. E. (1992). Growth and larval development of Nyctiphanes simplex in laboratory conditions. Calif. coop. ocean. Fish. Invest. Rep. 33: 162-171

Lavaniegos, B. E. (1993). Estructura de las poblaciones de eufáusidos (Crustacea) en la zona de transición de Punta Eugenia, Baja California, con referencia particular a la producción de Nyctiphanes simplex. Ph.D. thesis, Centro de Investigación Científica y de Educación Superior de Ensenada

Lavaniegos, B. E. (1994). Dispersion and development patterns in larvae of Nyctiphanes simplex (Euphausiacea) in the upwelling region off Baja California. Mar. Ecol, Prog. Ser 106: 207-225

Lindley, J. A. (1982). Population dynamics and production of euphausiids. III. Meganyctiphanes norvegica and Nyctiphanes couchi in the North Atlantic Ocean and the North Sea. Mar. Biol. 66: 37-45

Lynn, R. J., Simpson, J. J. (1987). The California Current System: the seasonal variability of its physical characteristics J geophys. Res. 92: 12.947-12.966

Lynn, R. J., Simpson, J. J. (1990). The flow of the undercurrent over the continental borderland off Southern California. J geophys. Res. 95: 12995-13008

Mauchline, J (1968). Development of the eggs in the ovaries of euphausiids and estimation of fecundity. Crustaceana 14: $1.55-163$
Mauchline, J., Fisher, L. R. (1969). The biology of euphausiids Adv. mar. Biol. 7: 1-454

McLain, D. R., Russell, E. B., Norton, J. G. (1985). Anomalous warm events in the Boundary Current Systems. Calif. coop. ocean. Fish. Invest. Rep. 26: 51-64

Olson, R. J. (1980). Synopsis of biological data on the Southern bluefin tuna Tunnus maccoyii (Castelnau, 1872). InterAm. trop. Tuna Comm. Spec. Rep. 2: 151-212

Peterson, W. T., Miller, C. B., Huchingson, A. (1979). Zonation and maintenance of copepod population in the Oregon upwelling zone. Deep Sea Res. 26A: 467-494

Pillar, S. C., Armstrong, D. A., Hutchings, L. (1989) Vertical migration, dispersal and transport of Euphausia lucens in the southern Benguela Current. Mar. Ecol. Prog. Ser. 53: $179-190$

Pillar, S. C., Stuart, V. (1989). Population structure, reproductive biology and maintenance of Euphausia lucens in the southern Benguela Current. J Plankton Res. 10: $1083-1098$

Reid, J. G., Roden, G., Willie, J. (1958). Studies of the California Current System. Calif. coop. ocean. Fish. Invest. Rep. 1: 27-57

Ritz, D. A., Hosie, G. W. (1982). Production of the euphausiid Nyctiphanes australis in Storm Bay, South-Eastern Tasmania. Mar. Biol. 68: 103-108

Roden, I. G. (1971). Aspect of the transition zone in the Northeastern Pacific. J. geophys. Res. 76: 3462-3475

Roger, C. (1976). Fecundity of tropical euphausids from central and western Pacific Ocean. Crustaceana 31: 103-105

Sears, R. (1987). The photographic identification of individual blue whale (Balaenoptera musculus) in the sea of Cortez. Cetus $7 \cdot 14-17$

Smiles, M. C. Jr, Pearcy, W. G. (1971). Size structure and growth rate of Euphausia pacifica off the Oregon coast Fish. Bull, U.S. 69: 79-86

Smith, P. E., Richardson, S. L. (1977). Standard techniques for pelagic fish and larvae surveys. FAO Fish. tech. Pap. 175 $1-107$

Stuart, V. (1992). Fecundity of Euphausia lucens (Hansen) laboratory evidence for multiple broods. J. exp. mar. Biol. Ecol. 160: 221-228

Stuart, V., Nicol, S. (1986). The reproductive potential of three euphausiids species from the southern Benguela region. J. exp. mar. Biol. Ecol. 103: 267-274

Walsh, J. J., Whitledge, T. E., Kelley, J. C., Huntsman, S. A., Pillsbury, R. D. (1977). Further transition states of the Baja California upwelling ecosystem. Limnol. Oceanogr. 22 $264-280$

Wyllie, J. G. (1966). Geostrophic flow of the California Current at the surface and at 200 meters. Calif. coop. ocean. Fish. Invest. Atlas 4: 1-288

Wyrtki, K. (1965). Surface current of the eastern equatorial Pacific Ocean. Inter-Am. trop. Tuna Comm. Bull. 5. $270-304$

Wyrtki, K. (1967). Circulation and water masses in the Eastern Equatorial Pacific Ocean. J. oceanol Limnol. 2: 117-147

Youngbluth, M. J. (1975). The vertical distribution and diel migrations of euphausiids in the central waters of the eastern South Pacific. Deep Sea Res. 22: 519-536

Youngbluth, M. J. (1976). Vertical distribution and diel migration of euphausiids in the central region on the California Current. Fish. Bull. U.S. 74: 925-936

Manuscript first received: April 29, 1994

Revised version accepted: November 23, 1994 